\title{
What do the Poles know about human papillomavirus (HPV)?
}

\section{Co Polacy wiedzą o wirusie brodawczaka ludzkiego (HPV)?}

\author{
Maisa Manasar', Alicja Gońda', Marta Mrokwa', Beata Bergler-Czop², Ligia Brzezińska-Wcisło² \\ 'Students' Scientific Society at Department of Dermatology, Medical University of Silesia, Katowice, Poland \\ 2Department of Dermatology, Medical University of Silesia, Katowice, Poland \\ 'Studenckie Koło Naukowe przy Katedrze i Klinice Dermatologii, Śląski Uniwersytet Medyczny, Katowice, Polska \\ 2Katedra i Klinika Dermatologii, Śląski Uniwersytet Medyczny, Katowice, Polska
}

Human papillomavirus (HPV) shows tropism to human cells of the basal layer of the skin epithelium and mucous membranes. The virus plays an important role in the development of cervical cancer and other malignant and proliferative skin lesions [1]. Among sexually transmitted diseases, HPV infection is an important epidemiological problem. In addition to sexual intercourse, the virus may also be transmitted vertically [2]. Protection against some types of the virus, including HPV-16 and HPV-18, is provided by vaccines of various efficacy, administered to women before their sexual initiation. The education of the patients about the need for prevention and regular screening for potential infection is the responsibility of physicians and other medical personnel $[3,4]$.

The aim of the study was to analyse the knowledge of Poles aged 18-40 years concerning the routes of infection, its consequences, and ways of preventing HPV infection. The survey was conducted anonymously between November 2017 and May 2018 on a representative group of random adults living in Poland. The survey was completed by 364 people living in regions of various urbanisation. The criteria for inclusion in the survey were: age between 18 and 40 years, minimum secondary education, and residence in Poland. The questionnaire consisted of the questions on the patients' background and demographic parameters and closed multiple- or singlechoice questions on the analysed subject. Statistical analysis was carried out with the use of Statistica 13 (StatSoft Poland). The probability of occurrence of differences was statistically significant with the value of $p<0.05$.

Of the 364 respondents to the survey, 291 (80.0\%) were women. Respondents aged 18-25 years were the dominant age subgroup (185 people; $50.8 \%$ ), and $204(56.0 \%)$ persons declared no connection with
Wirus brodawczaka ludzkiego (HPV) wykazuje tropizm do ludzkich komórek warstwy podstawnej naskórka i błon śluzowych. Zakażenie HPV odgrywa ważną rolę $\mathrm{w}$ rozwoju raka szyjki macicy oraz innych rozrostowych i złośliwych zmian skórnych [1]. Wśród chorób przenoszonych drogą płciową zakażenie wirusem HPV stanowi istotny problem epidemiologiczny. Oprócz stosunku seksualnego wirus może być również przenoszony drogą wertykalną [2]. Ochronę przed niektórymi typami wirusa, takimi jak HPV-16 i HPV-18, zapewniają szczepionki o różnym stopniu skuteczności, przeznaczone dla kobiet przed inicjacją seksualną. Edukacja pacjentów obejmująca konieczność stosowania profilaktyki i regularnych badań przesiewowych $\mathrm{w}$ kierunku potencjalnego zakażenia należy do obowiązków lekarzy i innych przedstawicieli personelu medycznego [3, 4].

Celem pracy była analiza stanu wiedzy Polaków w wieku 18-40 lat na temat dróg zakażenia wirusem $\mathrm{HPV}$, jego skutków oraz metod zapobiegania zakażeniu. Badanie zostało przeprowadzone anonimowo od listopada 2017 roku do maja 2018 roku na reprezentatywnej próbie losowo wybranych osób dorosłych mieszkających w Polsce. Ankiety uzyskano łącznie od 364 osób zamieszkujących regiony o różnym stopniu urbanizacji. Kryteria włączenia do badania obejmowały: wiek 1840 lat, wykształcenie minimum średnie oraz miejsce zamieszkania w Polsce. Kwestionariusz składał się z pytań dotyczących cech społeczno-demograficznych uczestnika (metryczka) oraz zamkniętych pytań wielokrotnego lub jednokrotnego wyboru związanych $\mathrm{z}$ badaną tematyką. Analizę statystyczną przeprowadzono z wykorzystaniem pakietu Statistica 13 (Statsoft Polska), a prawdopodobieństwo wystąpienia różnic uznawano za statystycznie istotne, gdy $p<0,05$.

Spośród 364 respondentów uczestniczących w badaniu 291 (80,0\%) stanowiły kobiety. Główną podgrupą wiekową (185 osób; 50,8\%) byli respondenci w wieku 
the health care industry. Almost 80\% (285; 78.3\%) of people chose the right answer for what the abbreviation HPV stands for. The most common ways of preventing HPV infection were condoms (268; 73.6\%) and vaccinations $(251 ; 69.0 \%)$. When asked about the consequences of HPV infection, the most common answers were cervical cancer $(309 ; 84.9 \%)$ and condyloma (179; 49.2\%). Concerning the high-oncogenic types of the virus, $222(61.0 \%)$ respondents declared a complete lack of knowledge in this area. While 107 (29.4\%) people chose the response containing types 16 and 18 of HPV, 35 (9.6\%) indicated the lowoncogenic virus types. Among the risk factors of HPV infection, the most frequently indicated was the change of sexual partners $(299 ; 82.1 \%)$, non-use of condoms $(276 ; 75.8 \%)$, and early sexual initiation $(187 ; 51.2 \%)$. Sexual contact was the most frequent answer $(327 ; 89.8 \%)$ concerning the sources of HPV infection, followed by the use of common cosmetic products $(136 ; 37.4 \%)$. Among the respondents, 61 $(16.8 \%)$ were vaccinated against HPV, including 59 $(20.3 \%)$ women and two $(2.7 \%)$ men $(p<0.05)$. There were $228(62.6 \%)$ respondents, including $179(61.5 \%)$ women and $49(67.1 \%)$ men $(p=0.37)$, who were aware of the existence of the vaccine but were not vaccinated by choice. Seventy-five $(20.6 \%)$ people did not know about the existence of HPV vaccination, including 53 (18.2\%) women and 22 (30.1\%) men $(p<0.05)$. Concerning the target population for the vaccination, 191 (52.5\%) respondents answered that it should be administered for both genders. Only female gender was indicated by 167 (45.9\%) persons, while only male gender by 6 persons. Among the respondents, 235 (64.6\%) answered that they would vaccinate their child, while 129 (35.4\%) would not. Most respondents $(197 ; 54.1 \%)$ indicated medical personnel as the primary source of knowledge about HPV. The media (Internet, television, radio) was marked by 180 (49.5\%) people. Among the surveyed, six people stated that they had not heard about the HPV virus before. In the summary, 281 (77.2\%) of the respondents stated that their knowledge of the subject was incomplete.

According to the survey, respondents' knowledge of HPV is insufficient and needs to be supplemented.

\section{CONFLICT OF INTEREST}

The authors declare no conflict of interest.
18-25 lat. Brak powiązań z sektorem ochrony zdrowia zadeklarowały 204 (56,0\%) osoby. Niemal 80\% osób (285; 78,3\%) wybrało właściwą odpowiedź na pytanie, co oznacza skrót HPV. Najczęściej stosowanymi sposobami zapobiegania zakażeniom wirusem HPV były prezerwatywy $(268 ; 73,6 \%)$ oraz szczepienia ochronne (251;69,0\%). W pytaniu dotyczącym skutków zakażenia wirusem HPV najczęściej podawano raka szyjki macicy (309; 84,9\%) i kłykciny kończyste (179; 49,2\%). Jeśli chodzi o typy wirusa HPV o wysokim ryzyku onkogennym, $222(61,0 \%)$ respondentów zadeklarowało całkowity brak wiedzy w tym zakresie, a 107 (29,4\%) osób wybrało odpowiedź zawierającą typy 16 i 18 wirusa HPV, 35 $(9,6 \%)$ ankietowanych wskazało typy wirusów o niskim ryzyku onkogennym. Wśród czynników sprzyjających zakażeniu wirusem HPV najczęściej wskazywano zmianę partnerów seksualnych $(299 ; 82,1 \%)$, nieużywanie prezerwatyw $(276 ; 75,8 \%)$ oraz wczesną inicjację seksualną $(187 ; 51,2 \%)$. Najczęstszą odpowiedzią na pytanie o źródła zakażenia HPV były kontakty seksualne (327; $89,8 \%$ ), a drugą w kolejności - używanie wspólnych produktów kosmetycznych $(136 ; 37,4 \%)$. Wśród respondentów 61 (16,8\%) osób było zaszczepionych przeciwko HPV, w tym 59 (20,3\%) kobiet i 2 (2,7\%) mężczyzn $(p<0,05)$. Ogółem $228(62,6 \%)$ respondentów - 179 $(61,5 \%)$ kobiet i $49(67,1 \%)$ mężczyzn $(p=0,37)$ - miało świadomość istnienia szczepionki przeciwko HPV, ale nie było zaszczepionych z wyboru. Z kolei 75 (20,6\%) osób, w tym 53 (18,2\%) kobiety i 22 (30,1\%) mężczyzn $(p<0,05)$, nie wiedziało o istnieniu szczepień przeciwko HPV. W przypadku docelowej populacji, jaka miałaby być objęta szczepieniami, 191 (52,5\%) respondentów stwierdziło, że szczepienia powinny być stosowane u obu płci. Wyłącznie płeć żeńską wymieniło 167 (45,9\%) osób, a wyłącznie płeć męską 6 osób. Spośród wszystkich respondentów 235 (64,6\%) osób zaszczepiłoby swoje dziecko przeciwko HPV, natomiast 129 (35,4\%) zrezygnowałoby ze szczepienia. Większość badanych (197; 54,1\%) wskazała personel medyczny jako podstawowe źródło wiedzy na temat wirusa HPV. Z kolei 180 $(49,5 \%)$ osób wymieniło w tym kontekście media (Internet, telewizję, radio). Spośród uczestników badania 6 osób stwierdziło, że wcześniej nie słyszało o wirusie HPV. Podsumowując - łącznie 281 (77,2\%) respondentów uznało, że ich wiedza na temat HPV jest niepełna.

Na podstawie wyników badania należy stwierdzić, że stan wiedzy respondentów na temat HPV jest niewystarczający i wymaga uzupełnienia.

\section{KONFLIKT INTERESÓW}

Autorzy nie zgłaszają konfliktu interesów. 


\section{References}

\section{Piśmiennictwo}

1. Egawa N., Egawa K., Griffin H., Doorbar J.: Human papillomaviruses: epithelial tropisms and the development of neoplasia. Viruses 2015, 7, 3863-3890.

2. Ryndock E.J., Meyers C.: A risk for non-sexual transmission of human papillomavirus? Exp Rev Anti Infect Ther 2014, 12, 1165-1170.

3. Bogani G., Maggiore U.L.R., Signorelli M., Martinelli F., Ditto F., Sabatucci I.: The role of human papillomavirus vaccines in cervical cancer: prevention and treatment. Crit Rev Oncol Hematol 2018, 122, 92-97

4. Sawaya G.F., Kulasingam S., Denberg T.D., Qaseem A.; Clinical Guidelines Committee of American College of Physicians.: Cervical cancer screening in average-risk women: best practice advice from the clinical guidelines Committee of the American College of Physicians. Ann Intern Med 2015, 162, 851-859.

Received: 26.01 .2019

Accepted: 19.10 .2019

Otrzymano: $26.01 .2019 \mathrm{r}$.

Zaakceptowano: $19.10 .2019 \mathrm{r}$. 